\title{
Partition of Bengal and the Reaction of Contemporary Students
}

\author{
Dr. Swapan Kumar Pain \\ Assistant Professor, Department of History, Raiganj University, West Bengal, India, PIN: 733134
}

\begin{abstract}
The partition of Bengal and subsequent swadeshi and boycott movement opened a new episode in the history of freedom movement of India. Though the movement started in Bengal it spread all over India. Starting from Bengal the agitation spread like wild fire in cities, towns and even villages where housewives, students and people of every corner in life participated to protest against the divisive policy of the Raj which was unprecedented in Indian history. A remarkable aspect of the movement was the widespread student participation all over Bengal, and in several other parts of India. The students showed the greatest enthusiasm and created swadeshi spirit in Bengal and also India. This movement had left a deep impact on literature, music, art, science and education of Bengal as well as India. The patriotism, sacrifice and courage of the students earned great respect from the common people.
\end{abstract}

\section{INTRODUCTION}

One of the most unpopular and terrible measure of the British Indian Government was the Partition of Bengal in 1905. Lord Curzon came to India (1899-1905) with a strong determination to curtail the rising tide of nationalism. The Calcutta Corporation Act (1899), The Indian Universities Act (1904) and the Official Secrets Act (1904) were some of the measures through which Curzon sought to curb the growing nationalistic and patriotic spirit. One of the main objects of the partition of Bengal was to break up the unity of the people of Bengal. Lord Curzon divided the territories of Bengal in such a way that the western part of Bengal including Bihar, Chota Nagpur and Orissa formed the Hindu majority and the eastern part of Bengal including North Bengal and Assam formed the Muslim majority area. The plan of partition announced in newspapers on $20^{\text {th }}$ July 1905 , and finally became operational on $16^{\text {th }}$ October 1905 . The partition of Bengal produced tremendous anti-British reaction among the Bengalis. The partition of Bengal and subsequent swadeshi movement opened a new episode in the history of freedom movement of India. Though the movement started in Bengal it spread all over India. Starting from Bengal the agitation spread like wild fire in cities, towns and even villages where housewives, students and people of every corner in life participated to protest against the divisive policy of the Raj with zeal quite unprecedented in Indian history. A remarkable aspect of the movement was the widespread student participation all over Bengal, and in several other parts of India. ${ }^{1}$ The students showed the greatest enthusiasm and created swadeshi spirit in Bengal and also India during the agitation.

\section{BACKGROUND OF STUDENT PARTICIPATION: THE DAWN SOCIETY}

Large sections of the society believe that the student movement began in the $20^{\text {th }}$ century in India. But this conception is incorrect. The activities of the students' in the $19^{\text {th }}$ and $20^{\text {th }}$ centuries have been hardly highlighted by the scholars or, historians. The student community played a glorious role in the history of India through their memorable struggle and contributions. The first two decades of the $20^{\text {th }}$ century was full of students' movement. A huge number of Students' Associations were emerged in those two decades. At the beginning of the $20^{\text {th }}$ century, we found the name of Dawn Society. It was very powerful student organization and purely non-political institute of culture, founded in 1902. The main spirit of the Dawn Society was Satish Chandra Mukherjee, a famous educationist and the editor of The Dawn, founded in 1897, which dealt with moral and spiritual ideas. He was assisted by Gurudas Banerjee, N. N. Ghosh, Sister Nivedita etc. It was formed mainly against the Indian Universities Commission and its unpopular report. The students thought that the report of the Universities Commission sought to destroy their identity, as well as educational system. A good number of educationists and students participated in the Dawn Society. ${ }^{2}$ They demanded that the educational structure of India must be changed. They also advocated the bases of Swadeshi educational institutions which became an important part of the Swadeshi and anti-partition movement.

Another important objective of the Dawn Society was to teach moral and religious education to the students and to make them self-reliant. In 1903, they opened a Swadeshi Store to sell the home made goods. It was managed totally by the young students in the afternoon. The mouthpiece of the Dawn Society was The Dawn, regularly published the notes and news on the Indian economy. It proved that the swadeshi activities of the Dawn Society began much before the formal movement of 1905. After the announcement of partition of 
Bengal, the Dawn Society convened a meeting in which Satish Chandra Mukherjee, Rabindranath Tagore and Hirendranath Datta were present. Satish Chandra urged the students to sever connection with the official university and boycott its exams. They demanded the immediate establishment of a National University to promote national education. ${ }^{3}$

\section{ANTI-CIRCULAR SOCIETY}

In July, 1905, the plan of partition had been opposed through an intensive use of the conventional moderate methods of press campaign, numerous meetings and petitions. The student community threw itself into the movements. A big Conference was held in the Town Hall of Calcutta in which the delegates of the students were spectacular. It was evident that total failure of such techniques led to a search for new way i.e. the boycott of British goods. They led the movement by holding pickets before the shops selling foreign goods and burning foreign clothes. In fact, never before had the students of Bengal been involved in such movement. Schools and college students in batches boycotted their classes to devote themselves to swadeshi activities. As expected, the British Indian Government took repressive measure to suppress the movement. The Government was terribly anxious at the student movement and so was forced to issue the infamous Carlyle Circular in order to put down the movement. It was named after the officiating chief secretary to the Government of Bengal R. W. Carlyle and was issued on $10^{\text {th }}$ October 1905 . The Circular prohibited the students from attending the meetings of the nationalist leaders or from boycotting, picketing or other activities associated with the swadeshi movement. ${ }^{4}$ Even, shouting Vande Mataram was banned. The Carlyle Circular also threatening withdrawal of grants, scholarships and affiliation from nationalist dominated institutions led to a movement for boycott of official educational institutions and organizations of national schools which received a great incentive from the impressive donation of rupees one lac by Subodh Mullick. ${ }^{5}$ The publication of Carlyle Circular created sensation and a sense of shock all over the country. As a protest against the notorious circular, a vast student meeting was convened at College Square on $4^{\text {th }}$ November 1905, Calcutta and the outcome of the meeting was the formation of Anti-Circular Society under the leadership of Sachindranath Basu and Ramakanta Roy. ${ }^{6}$

After the formation of Anti-Circular Society, the students undertook fund collection, campaigns for swadeshi goods and for national educational institutions under the banner of the society. The members of the society also arranged for continuance of the studies of those students who were victimized by the authorities. ${ }^{7}$ Krishna Kumar Mitra and his newspaper Sanjivini supported the students. They also popularized the national songs. In support of the Anti-Circular Society, Satish Chandra Mukherjee and his Dawn Society stepped forward. The Calcutta University was regarded as 'Goldighir Golam Khana'. The Anti-Circular Society had opened 75 Certres for selling swadeshi clothes and within 11 months more than one lakh rupees were earned by selling clothes. ${ }^{\mathbf{8}}$ The students hawked clothes from door to door.

It was very significant that during the swadeshi and boycott movement, the student volunteers of the Anti-Circular Society projected a National Flag of their own and handed over it to Surendranath Banerjee and his associates. In that projected flag, there was a tri coloured base- Red, Green and Yellow; in the middle of the flag, the students sketched eight half-bloom lotuses which marked as a symbol of the then eight provinces of India. They also sketched the sun and half moon on the flag to symbolize Hindu-Muslim unity. ${ }^{9}$ In the middle was written in Devangiri script: Vande Mataram. ${ }^{\mathbf{1 0}}$

The Anti-Circular Society was the mass student base organization. Its activities were spread to Dhaka, Naokhali, Mymansingh, Barisal, Jessore, Medinipur, Bankura and many other places. At this time the national consciousness of the students began to take shape. ${ }^{11}$ The leaders of the society went to Jessore in February 1906, to restore communal harmony because there was a danger of riots in the place. In the Annual Report of the Society in 1906, Sachindranath Basu appealed the students to work for Hindu-Muslim unity. In the month of April 1906, at the Barisal Conference under the chairmanship of Abdul Rasul, the Anti-Circular Society defied ban on Vande Mataram boldly. After that Sachindranath Basu and his associates were beaten by the British police and one of them was almost beaten to death, but he kept on shouting Vande Mataram. ${ }^{12}$ It is to be noted that the activities of the apolitical students during that period was astonished the people. From the period 1905 to 1908, the movements of the students got its highest height and expectedly the Colonial Government brutally attacked the student leaders and even a number of students imprisoned in jails. ${ }^{13}$

Such a perspective of slow and unostentatious development of what Rabindranath called Atmasakti or self-strengthening had little appeal to the excited educated youth of Bengal. In another field, a considerable variety may be noticed within the national education efforts in Swadeshi Bengal, ranging from pleas for more technical training, through advocacy of vernacular medium. ${ }^{14}$ After a couple of years the Bengal National College and a Bengal Technical Institute was set up. It was evident that a dozen of national schools in Bengal were also set up to spread the vernacular education. 


\section{NATURE OF THE MOVEMENT}

There was a great debate among the scholars about the student participation in the anti-partition or swadeshi and boycott movement. The character and trend of this movement were different from all previous movements of the $19^{\text {th }}$ century. So from the stand point of achievement its importance could not be judged. A section of scholars had opined that the Muslim students did not show their solidarity to the movements. Dr. Hannan, a noted Bangladeshi historian said the middle class Muslims of East Bengal supported the partition of Bengal on the ground that Dhaka was announced as their new capital. But a number of Muslim politician and student leaders involved in the anti-partition movement and even took the leading role. Muslim Student leaders like Abdul Rasul, Abdul Halim Gajnavi, Moniruzzaman Islamabadi, Moulabi Kazim Ali, Syed Ismail Hossain Siraji, Abul Qasim, Mujibur Rahaman, Moulana Akram Khan, Dr. Abdul Gaffur Siddhiki, Syed Ali Imam, Hassan Imam, Mojarul Hoque, Liyakat Hussain were prominent. These Muslim student leaders were participated in the anti-partition movement with full strength and showed solidarity to the nationalist leaders of the movement. ${ }^{15}$

One of the most important characteristics of the movement was the active participation of the Hindu and Muslim zamindars of East Bengal. They apprehended that their zamindary system may be abolished on the ground of partition. The ordinary people were agonized and frustrated with the inhuman attitude of the zamindars and exploitation by the zamindary system. ${ }^{\mathbf{1 6}}$ Another peculiar characteristics of the student participation in the anti-partition movement was that the students of mofussil area either reluctant or noninterested. The contemporary Newspapers and Periodicals do not provide us any information of the mofussil students on anti-partition movement. During 1905-1908 Bengal mofussil students was not prepared to expedite their solidarity on the issue of the partition.

During the anti-partition movement many items like ink, nibs and matches were produced locally and the students used these swadeshi goods. Much student involvement in the movement also attracted the attention of the British Parliament. In a parliamentary session, dealing with the educational institutions of Government prosecutions against students, Dr. Ratherford asked the Secretary of State for India whether his attention had been drawn to occurrences of such cases or not. ${ }^{17}$

\section{IMPACT}

The student participation and their active involvement in the anti-partition or swadeshi and boycott movement had left a deep impact in a number of ways. Its impact was felt at every stage in the life of Bengal and also of India in the arena of literature, music, art, science and education. The patriotism, sacrifice and courage of the students earned great respect from the common people. Influence of the student movements have been perhaps most pronounced in the literary and cultural life of the state. In literature, writers and poets have introduced a new tone and outlook. ${ }^{18}$ The agitating students habitually recite their poems in the various meetings and demonstrations. In the public meetings, rallies and demonstrations the agitating students staged dramas, which helped to create a new outlook. In addition to these, the students brought out many leaflets, booklets, Chharas or rhymes which also influenced the common masses of Bengal. The famous song of Rabindranath Tagore 'Banglar Mati, Banglar Jal' i.e. soil and climate of Bengal was composed in the light of swadeshi movement. On the other hand, political leaflets were extensively circulated amongst the students. Political songs of Bankim Chandra Chattopadhyay's Anandamath were memorized by the students. The students were also used to held exhibition where paintings of Lala Lajpat Rai, Aurobindo Ghosh, Bipin Chandra Pal were displayed. ${ }^{19}$ The agitating students spread the anti-partition movement from Bengal to other parts of the country especially South India. Bipin Chandra Pal took the leading role to spread the movement in south. In 1907, He visited Vizagapatnam, Madras, Rajahmundhry etc. for delivering lectures on the movement and got a tremendous response from the students of south. Even the student of Madras bears the expenses of his visit. ${ }^{20}$

Ultimately, the British Indian Government bowed down to public opinion and repealed the Partition Act in 1911.But there was no restoration of the former condition of Bengal and marked as the most unfortunate tragedy in the history of Bengal. It heralded the path of success for any future upheaval.

\section{REFERENCES}

[1]. Rajimwale, Anil: History of Student Movement in India: Origins and Development (1920-1947), Manak Publications Pvt. Ltd., New Delhi, 2001, p.44

[2]. I bid.

[3]. Majumdar Ramesh Chandra: History of the Freedom Movement in India, Vol. II, Firma K. L. M., Calcutta, 1963, pp.75-76 
[4]. Majumdar R. C.: op. cit. p. 62

[5]. Sarkar, Sumit.: Modern India: 1885-1947, Macmillan, New Delhi, 1983, pp. 111-112

[6]. Chattopadhyay Gautam: Bengal's Student Movement in Challenge: A Saga of India's Struggle for Freedom, People's Publishing House, New Delhi, 1984, p. 515

[7]. Rajimwale, Anil: op. cit. p. 47

[8]. Chattopadhyay Gautam: op. cit. p. 516

[9]. Dasgupta, H. and Adhikary, H.: Rajnaitik Poto Bhumite Bharatiya Upamahadesher Chhatra Andolan (In Bengali), School for People, Medinipore, 1993, and Radical Impression, Kolkata, 2008, pp. 25-26

[10]. Chattopadhyay Gautam: op. cit. p. 516

[11]. Rajimwale, Anil: op. cit., p.44

[12]. Chattopadhyay Gautam: op. cit. p. 516

[13]. Mohammed Hannan: History of Student Movement of Bangladesh; 1830-1971, Osman Goni Agamee Prakashani, Dhaka, Bangladesh, 1999, p. 32

[14]. Sarkar, S.: Modern India: 1885-1947, Macmillan, 1983, p. 112 and also see The Swadeshi Movement in Bengal

[15]. Mohammed Hannan: op. cit. p. 30

[16]. I bid.

[17]. Rajimwale, Anil: op. cit. p. 47

[18]. Ray, Sudhir: Marxist Parties of West Bengal: 1947-2001, Progressive Publisher, Kolkata, 2001, pp. 253255

[19]. Rajimwale, Anil: op. cit. p. 49

[20]. V. Sankaran Nair: Swadeshi Movement; The Beginnings of Student Unrest in South India, Mittal Publications, Delhi, 1985, pp. 43-45 